\title{
AN IMMUNOHISTOCHEMICAL STUDY OF THE NEUROPEPTIDERGIC BAG CELLS OF APLYSIA ${ }^{1}$
}

\author{
ARLENE Y. CHIU ${ }^{2}$ AND FELIX STRUMWASSER ${ }^{3}$
}

Division of Biology, California Institute of Technology, Pasadena, California 91125

\begin{abstract}
The bag cell neurosecretory system of Aplysia californica synthesizes and releases a neuropeptide, the egg-laying hormone (ELH), which can induce egg-laying behavior. While ELH acts as a neurohormone on distant neuronal and non-neuronal targets, it also can moderate the electrical activity of neurons within the abdominal ganglion. Using antibodies generated against pure ELH, our immunohistochemical study provides direct morphological support for this dual function of ELH by defining the distribution of this neuropeptide within the abdominal ganglion of $A$. californica. We also find ELH cross-reactivity in the bag cell systems of three other species of Aplysia.

In sections of abdominal ganglia stained for ELH by the peroxidase-antiperoxidase method, bag cell clusters were found to be homogeneous populations of ELH-immunoreactive neurons, extending processes in a complex array within the connective tissue sheath overlying the ganglion and the proximal regions of neighboring nerves. This association of neurites with the sheath is the neurohemal organ which facilitates release of ELH into circulating hemolymph. Stained processes also invade the interior of the ganglion in association with septal sheets of connective tissue and as scattered fibers in the neuropil. Local modulation by ELH probably occurs through release from these intraganglionic sites. A few ELH-positive ectopic cells were seen outside of the confines of the bag cell clusters as far displaced as the base of the branchial nerve; they appear to be bag cells which have mis-migrated during development. Specificity of the antiserum was confirmed by the total lack of staining of all other neurons within the abdominal ganglion as well as the absence of staining of bag cells with pre-immune serum.

Although the ELHs of Aplysia vaccaria, Aplysia braziliana, and Aplysia dactylomela have not been characterized biochemically, it is known that abdominal ganglion extracts from $A$. californica can induce egg laying in all three species. We find that antiserum against $A$. californica ELH stains the bag cell systems of $\Lambda$. vaccaria, $A$. braziliana, and $A$. dactylomela and not other parts of their abdominal ganglia. It is likely that this staining represents cross-immunoreactivity of the egg-laying neurohormones from these species which also share cross-bioactivity.
\end{abstract}

The classical neurosecretory cell synthesizes, transports, and releases a peptidergic neurohormone(s) into portal, systemic, or hemocoelic circulation for distribution to distant targets. However, recent experimental

\footnotetext{
'We thank Drs. J. Vaughan and R. Barber for instruction on peroxidase-antiperoxidase (PAP) methodology, Dr. J. Brockes for advice on enzyme-linked immunosorbent assay (ELISA) and immunofluorescence techniques, D. Viele for assistance in tissue culture, and Dr. L. K. Kaczmarek for comments on an earlier draft of this paper. Aplysia californica and Aplysia vaccaria were collected by J. Scotese; Aplysia dactylomela was generously supplied by Dr. M. DunlapSwitzer and Aplysia braziliana abdơminal ganglia were furnished by J. Yeakley. This work was supported by National Institutes of Health Grant NS15183 to F. S. Predoctoral support from the Lawrence A. Hanson Foundation for A. Y. C. is gratefully acknowledged.

${ }^{2}$ Present address: Department of Physiology and Biophysics, Washington University School of Medicine, 660 South Euclid, St. Louis, MO 63110.

${ }^{3}$ To whom reprint requests should be sent.
}

data now suggest a far broader role for many neurohormones. Immunohistochemistry has revealed the widespread presence of classical vertebrate neurohormones outside of the hypothalamus (Swanson, 1977; Silverman and Zimmerman, 1978; Jackson and Reichlin, 1979; for review, see Elde and Hökfelt, 1978); some have been localized specifically within conventional neurons and terminals in the central and peripheral nervous systems (Jan et al., 1980; Elde and Hökfelt, 1978). Electrophysiological studies demonstrate that neuropeptides can have profound and specific effects on the electrical activities of other neurons (Dyer and Dyball, 1974; Jan et al., 1979; for review, see Renaud and Padjen, 1977). Moreover, posterior pituitary peptides have been implicated in memory processes (de Wied and Verskeg, 1979) and luteinizing hormone releasing hormone in sexual behavior (Moss, 1979). Now it is believed that neuropeptides, including neuroendocrine peptides, may be acting as modulators or as bona fide transmitters within the ner- 
vous system. Most recently, the intriguing finding that a neuroactive peptide and a conventional neurotransmitter can coexist within a single neuron has raised further speculations about the roles peptides may play in neurochemical communication (Hökfelt et al., 1980a, b).

In Aplysia, two clusters of 800 peptidergic neurons, located at the junctions of the pleurovisceral connectives (PVCs) and the abdominal ganglion, release a neuropeptide, the egg-laying hormone (ELH), which is the "command" for a stereotyped program of egg-laying behavior. 'These bag cell neurons are characterized by unique electrophysiological properties, such as synchronization and long lasting afterdischarge following a brief synaptic stimulus (Kupfermann and Kandel, 1970; Blankenship and Haskins, 1979), and biochemical products which relate to their functions as neurosecretory cells. During an afterdischarge, they release a heterogeneous mixture of at least four peptides (Stuart et al., 1980) for peptide release induced by high $\mathrm{K}^{+}$, see Arch, 1972; Loh et al., 1975). One of these neurosecretory peptides, ELH, has been purified recently and its amino acid sequence has been determined (Chiu et al., 1979a). It is a 36-aminoacid, basic molecule which, when injected into a test animal, induces egg-laying and associated behavior (for review, see Arch, 1976; Strumwasser et al., 1980). In this study, we have sought to determine the distribution of this endogenous molluscan neuropeptide in sections of Aplysia abdominal ganglion and in cell culture by conventional immunohistochemical procedures.

Histological and cytological studies of bag cell clusters suggest that they contain only one type of neuron based on the size and appearance of secretory granules $(\sim 170$ nm) (Coggeshall, 1967) and on basic stains (Smock and Arch, 1977). The electrophysiological properties of bag cells within a cluster also appear similar (Kupfermann and Kandel, 1970; Blankenship and Haskins, 1979; Kaczmarek et al., 1979). However, a functional and biochemical criterion for a homogeneous population of neurosecretory cells requires all bag cells to synthesize and release ELH. Our results demonstrate the presence of ELH immunoreactivity in all somata within the bag cell clusters of four species of Aplysia, while other abdominal ganglion neurons remain unreactive. Hence, it is likely that the release of a set of heterogeneous peptides from bag cells during afterdischarge (Stuart et al., 1980) is not explained by subpopulations of bag cells, each releasing a different peptide.

From neurophysiological data, it has been postulated that bag cells exert a neuromodulatory influence on other neurons in the abdominal ganglion via a "local hormonal action" (Mayeri, 1979). It is important, therefore, to localize possible sites of release where such local effects can occur. Earlier studies have discussed the presence of processes, within the overlying sheath, with a high content of neurosecretory granules, similar to those found in bag cell somata (Frazier et al., 1967). However, the obvious limitations of ultrastructural studies prevent a complete visualization and understanding of the organization of the bag cell system. Using a specific bag cell product, ELH, as marker, our studies are the first to demonstrate, at the light microscopic level, the topography and distribution of hormone-bearing processes in the neurohemal areas of the connective tissue sheath enveloping the ganglion as well as within the abdominal ganglion.
The principle of parsimony in nature raises the expectation that mechanisms of neuroendocrine regulation and modulation, revealed through simple invertebrate systems, would apply to the more complex and often inaccessible systems in vertebrates. The bag cell system, consisting of two groups of homogencous neurons which release peptide signals, one with presently known structure and function, provides a model for understar. ding how a neuropeptide regulates stereotyped behavior.

Antibodies which recognize ELH also allow us to probe for other neurons in the Aplysia nervous system which bear ELH or ELH-like molecules (A. Y. Chiu and F. Strumwasser, manuscript in preparation). Recently, an egg-releasing peptide, purified from the atrial gland of the reproductive tract of Aplysia californica, is reported to share regions of homology with ELH (Schlesinger et al., 1981). Perhaps, like the diverse endorphins in vertebrates, there exists a family of ELH-like molecules with different functions, distributions, and varying degrees of bioactivity. The occurrence of related families of peptide messengers within the same organism may eventually turn out to be traceable to the earliest nervous systems. An abstract of some of this work has appeared (Chiu et al., 1979b).

\section{Materials and Methods}

Generation and partial purification of antibodies. $\mathrm{ELH}$, labeled with [ $\left.{ }^{3} \mathrm{II}\right] \mathrm{leucine}$ and purified to homogeneity as described elsewhere (Chiu et al., 1979a), was desalted by dialysis (Spectrapor 3 membrane, cut-off $M_{\text {. }}$. $=3500$; Spectrum Medical Industries) or by passage through a $20.0 \times 1.0 \mathrm{~cm}$ column of P-2 (Bio-Rad, minus 400 mesh) equilibrated in $1 \mathrm{M}$ acetic acid. Approximately $0.5 \mathrm{mg}$ of ELH was lyophilized and redissolved in $50 \mu \mathrm{l}$ of distilled water. An equal volume of thyroglobulin $(\mathrm{Tg}$; Sigma, $10 \mathrm{mg} / \mathrm{ml}$ in distilled water) was added with 2.5 $\mathrm{mg}$ of 1-ethyl-3-(3-dimethylaminopropyl)carbodi-imide $\mathrm{HCl}$ (Sigma) as the coupling agent. Incubation at room temperature for 1 to $3 \mathrm{hr}$ was followed by dialysis against distilled water to remove unreacted carbodi-imides. Material retained after dialysis was mixed with an equal volume of Freund's complete adjuvant (Difco Laboratories) for primary immunizations.

Multiple site, intradermal injections were given to two female New Zealand rabbits according to the method of Vaitukaitis et al. (1971). About $0.6 \mathrm{mg}$ of the ELH-Tg complex, containing coupled as well as unreacted hapten and carrier, in a total volume of 2 to $3 \mathrm{ml}$ was injected at 15 to 20 sites on the backs of the animals. After 4 to 6 weeks, the animals received intravenous booster injections of 50 to $150 \mu \mathrm{g}$ of ELH-Tg complex in phosphatebuffered saline (PBS, $0.1 \mathrm{~m}$ sodium phosphate, 0.9\% $\mathrm{NaCl}, \mathrm{pH} \mathrm{7.5),} \mathrm{and} \mathrm{the} \mathrm{harvesting} \mathrm{of} \mathrm{antisera} \mathrm{was} \mathrm{started}$ a week later. Protein content in solutions of ELH or ELH-Tg complex was estimated by absorbance at 215 $\mathrm{nm}$.

Partial purification of $\gamma$-globulins (IgG) from immune and pre-immune sera included precipitation by $50 \%$ saturated ammonium sulfate, followed by ion exchange chromatography on a Whatman DEAE-cellulose DE52 column and a second ammonium sulfate precipitation (Garvey et al., 1977). After dialysis against PBS to remove excess salt, the total protein in these IgG fractions was estimated from absorbance at $280 \mathrm{~nm}$. All antisera were kept frozen in aliquots until used. 
Antibodies specific for $\mathrm{Tg}$ were removed by passing whole sera through an affinity column of cyanogen bromide-activated Sepharose $4 \mathrm{~B}$ coupled to Tg according to the method of March et al. (1974). The column contained a maximum of $7 \mathrm{mg}$ of $\mathrm{Tg}$ coupled to $2.5 \mathrm{ml}$ of packed resin and equilibrated in $0.3 \mathrm{~m}$ borate buffer, $\mathrm{pH} 8.7$. Two milliliters of immune sera was applied and allowed to incubate at $15^{\circ} \mathrm{C}$ for $10 \mathrm{~min}$ before outflow from the column was resumed. Fractions containing protein which did not bind to the Tg-Sepharose column were pooled; the column was washed with borate buffer until absorbance at $280 \mathrm{~nm}$ was undetectable. Tg-specific antibody then was eluted with a $0.2 \mathrm{M}$ glycine/ $\mathrm{HCl}$ buffer, $\mathrm{pH} 2.4$. With the column re-equilibrated in borate buffer, the cycle was repeated by reapplying the pooled unbound protein fractions until no more protein was detected on elution with glycine/ $\mathrm{HCl}$ buffer. The recycled unbound protein fractions, now containing immune IgG minus anti- $\mathrm{Tg}$ (antisera $\mathrm{C}$ ), then were pooled and purified for IgG as described above. Pre-immune sera is designated antisera $\mathrm{A}$; whole immune sera is antisera $\mathrm{B}$.

Enzyme-linked immunosorbent assay (ELISA). ELISA was carried out according to Engvall and Perlmann (1972), with slight modifications, for quantitation of antibodies against ELH and Tg. All reactions were performed in microtiter plates (Scientific Products) and kept in a moist chamber during incubations. Antigens were diluted (ELH at $5 \mu \mathrm{g} / \mathrm{ml} ; \mathrm{Tg}$ at $20 \mu \mathrm{g} / \mathrm{ml}$ ) in 100 mM sodium carbonate buffer, $\mathrm{pH} 9.6 ; 35 \mu \mathrm{l}$ of either antigen solution was added to each microwell for overnight incubation at $4^{\circ} \mathrm{C}$. The coated wells were washed with four changes of $200 \mu \mathrm{l}$ of PBS/Tween $(50 \mathrm{~mm}$ sodium phosphate buffer, $0.9 \% \mathrm{NaCl}, \mathrm{pH} 7.4$, with $0.05 \%$ Tween20 ) followed by a 2- to 4-hr incubation at room temperature with $50 \mu \mathrm{l}$ of antisera, diluted with PBS/Tween, which prevents nonspecific adhesion of antisera but does not interfere with antibody-antigen binding. After microwells were rinsed well again, $50 \mu \mathrm{l}$ of goat-anti-rabbit alkaline phosphatase conjugate (Miles) at a dilution of 1 : 50 in PBS/Tween was added and plates were incubated overnight at $37^{\circ} \mathrm{C}$. Enzyme activity was revealed by reacting bound enzyme with $40 \mu \mathrm{l}$ of $1 \mathrm{mg} / \mathrm{ml}$ of $p$ nitrophenyl phosphate (Sigma) in $50 \mathrm{~mm}$ sodium carbonate, $\mathrm{pH} 9.8$, with $1 \mathrm{~mm} \mathrm{MgCl}_{2}$ for $15 \mathrm{~min}$ at $37^{\circ} \mathrm{C}$. Reaction was stopped with the addition of $50 \mu \mathrm{l}$ of $4 \mathrm{~N}$ $\mathrm{NaOH}$ and the antisera titer was expressed as absorbance at $405 \mathrm{~nm}$.

Peroxidase-antiperoxidase (PAP) staining of ganglion sections. Freshly dissected abdominal ganglia were fixed in $3.7 \%$ formaldehyde solution of Leibovitz L-15 (Gibco) for at least $24 \mathrm{hr}$ at $4^{\circ} \mathrm{C}$. After several hours of rinsing in L-15 to remove excess formaldehyde, the tissue was cryoprotected in $30 \%$ sucrose for $24 \mathrm{hr}$ at $4^{\circ} \mathrm{C}$. Whole ganglia then were frozen rapidly in OCT compound (Miles) over dry ice and $40-\mu \mathrm{m}$ frozen sections were cut on a cryostatic microtome. Sections were thawed rapidly and rinsed well in PBS and treated with sodium nitroferrocyanide according to the method of Straus (1971) to inactivate endogenous peroxidase activity before incubation with immunohistochemical reagents.

All incubations with antisera were carried out for 30 min to $1 \mathrm{hr}$ at room temperature with mild agitation.
Tissue was rinsed for $2 \mathrm{hr}$ in several changes of PBS following the use of each serological reagent. All serological agents were absorbed against acetone pellets of extracts of Aplysia head ganglia to reduce nonspecific background staining; dilutions were made in PBS. Following a short preincubation in whole goat serum (Gibco, 1:20 dilution), experimental sections were incubated with a $0.2 \mathrm{mg} / \mathrm{ml}$ solution of antisera C IgG, while control sections were incubated in a similar concentration of antisera A IgG (pre-immune IgG). Then, all sections were incubated in goat-anti-rabbit serum (Miles, diluted 1:20), followed by incubation in rabbit peroxidase-antiperoxidase (Bionetics, 1:20 dilution). Horseradish peroxidase reaction product was visualized by reaction in $3,3^{\prime}$-diaminobenzidine $/ 4 \mathrm{HCl}$ (Sigma, $0.6 \mathrm{mg} / \mathrm{ml}$ in PBS) and $0.006 \% \mathrm{H}_{2} \mathrm{O}_{2}$ for $15 \mathrm{~min}$. After a final rinse in PBS, the sections were floated on $5 \%$ gelatin in $50 \%$ ethanol and picked up on microscope slides precoated with $0.5 \%$ gelatin with $0.05 \%$ chromium potassium sulfate. The sections on slides then were dehydrated in ethanol, cleared in xylene, and mounted with Permount for viewing.

Immunofluorescent staining of tissue-cultured cells. Tissue cultures of bag cells from Aplysia californica were generated on microcoverslips as described elsewhere (Strumwasser et al., 1978) and maintained at $15^{\circ} \mathrm{C}$ in L-15 medium supplemented with $0.5 \%$ neomycin and polymyxin $B$ for 3 to 4 days. The medium in the culture dishes was replaced gradually by $3.7 \%$ formaldehyde in $\mathrm{L}-15$ at $15^{\circ} \mathrm{C}$ and fixation of cells was allowed for $15 \mathrm{~min}$. The cells were always kept immersed as they ruptured if exposed to air at this stage. The fixative was removed by several rinses of filtered sea water, followed by increasing concentrations of ethanol. When the cells were finally in $100 \%$ ethanol, they were incubated in an ice cold solution of $5 \%$ acetic acid in ethanol and kept for $15 \mathrm{~min}$ at $-20^{\circ} \mathrm{C}$, followed by a gradual rehydration at room temperature in PBS. Binding with different sera was carried out by applying 150 to $200 \mu \mathrm{l}$ of reagent onto cells on coverslips balanced on rubber stoppers inside a moist chamber at room temperature for $30 \mathrm{~min}$ to $1 \mathrm{hr}$. A preincubation with whole goat serum was followed by the first layer of primary rabbit IgG (antisera $\mathrm{A}$ or $\mathrm{C}$ ) and a second layer of fluorescein isothiocyanate-conjugated goat-anti-rabbit antibodies (Cappel Laboratories) at a dilution of 1:30. Between layers, the cells were returned to separate culture dishes and rinsed extensively in PBS for $1 \mathrm{hr}$. After staining and final rinses in PBS and distilled water to remove excess antibody, the coverslips were mounted on slides with ultraviolet inert mountant (Hopkin and Williams) and sealed with nail varnish. Slides were viewed with a Leitz Diavert microscope illuminated with light from a 200-W mercury lamp filtered through a BG 12 filter.

Animals. Most of the A. californica were collected at the Palos Verdes Peninsula from September 1979 to March 1980 and were mature (body weights $\geq 150$ gm; reproductive tract weights $\geq 0.9 \mathrm{gm}$ ); two exceptionally large animals (body weights $>3 \mathrm{~kg}$, reproductive tract weights, $20 \mathrm{gm}$ ) were obtained from the Monterey Peninsula. Aplysia vaccaria also were collected off the Palos Verdes Peninsula between October 1979 and February 1980; the Aplysia dactylomela was obtained from Ha- 
waii. These animals were maintained in aerated sea water at $20^{\circ} \mathrm{C}$, until sacrificed. Aplysia braziliana, collected at Padres Island, TX, were dissected immediately and their ganglia were preserved in fixative as described above.

\section{Results}

Presence of antibodies specific for ELH. Purified ELH and $\mathrm{Tg}$ were reacted separately against IgG fractions of antisera $\mathrm{A}, \mathrm{B}$, and $\mathrm{C}$ by ELISA to determine whether antibodies specific for the hapten had been generated. Figure 1 shows that immune sera (B) had an apparent higher titer of anti-Tg antibodies than antibodies which bind to ELH. However, while specific removal of anti-Tg antibodies by affinity chromatography greatly reduced the response of antisera $\mathrm{C}$ to $\mathrm{Tg}$ (Fig. 1, lower graph), there is an increase in the response of antisera C to ELH (Fig. 1, upper graph). Antisera C IgG fractions thus are enriched for anti-ELH antibodies which do not recognize determinants on the carrier molecule. As expected, preimmune sera (A) shows no response to either antigen.

Approximately $7 \mathrm{mg}$ of total protein was recovered in the IgG fractions from $1 \mathrm{ml}$ of antisera $\mathrm{A}, 34 \mathrm{mg} / \mathrm{ml}$ of antisera $B$, and $14 \mathrm{mg} / \mathrm{ml}$ of antisera $\mathrm{C}$.

Peroxidase-antiperoxidase staining of abdominal ganglion of Aplysia californica. A pocket of connective tissue encloses 200 to 400 bag cell somata at the junction of the abdominal ganglion and each pleurovisceral connective (PVC) nerve. In immunostained sections, all of the somata within a bag cell cluster show strong, positive immunoreactivity for ELH in contrast to the great majority of neurons in the rest of the ganglion (Fig. 2, $A$ and $B$ ). In the 12 abdominal ganglia examined, none of the other neurons stained for ELH except for a few ectopic bag cells described later. No immunoreactivity was ever seen in sections stained with pre-immune antisera A (Fig. $3 B)$.

Within bag cells, perinuclear staining is intense, while the nuclei remain free of stain. Bag cell somata appear ovoid with a mean major somal diameter of $87 \mu \mathrm{m}$ and a minor somal diameter of $62 \mu \mathrm{m}$ when averaged over six animals. Mean nuclear major and minor diameters measure 47 and $29 \mu \mathrm{m}$, respectively (Table I). Within the cluster, stained processes are relatively sparse, suggesting that each bag cell may send out only a small number of neurites to the periphery or that the detectability of ELH was limiting in finer processes. Extensive branching of these ELH-bearing processes occurs within the connective tissue sheath at the rim of the cluster and radiates out over the whole abdominal ganglion (Fig. $2 B$ ). These neurosecretory processes are densest over the bag cell clusters and can be traced medially to the region of connective tissue between clusters at the rostral margins of the ganglion (Fig. 3A, arrow). The density of bag cell processes diminishes with distance from the clusters, but stained processes often can be seen to extend to the caudal edge of the abdominal ganglion (Fig. 2, $A$ to $C$, arrows).

Immunoreactive neurites invade the PVCs in two ways. Within the thick connective tissue sheath of the proximal PVC, processes radiate toward the outermost surface. These neurosecretory processes seldom extend anteriorly beyond $1 \mathrm{~cm}$ from the clusters. Immunoreac- tive processes also spiral around the PVC nerve to form a cuff between the longitudinally oriented axons traveling to the pleural ganglion and the external cylinder of connective tissue sheath (Fig. 2, $C$ and $D$ ). This circularly oriented cuff of processes extends farther into the PVC than the radiating neurites described above, and though they also diminish in intensity as they travel away from the clusters, faint staining can be seen as far as $2 \mathrm{~cm}$ anteriorly into the PVC. In the majority of A. californica examined (body weight $\geq 150 \mathrm{gm}$; reproductive tract weight $\geqq 0.9 \mathrm{gm}$ ), there is no discernible staining as one proceeds anteriorly in the PVC until within $1 \mathrm{~cm}$ of the pleural ganglia. Immunoreactive processes at this other extreme of the PVC appear to emanate from cells in the head ganglia and are independent of the bag cell system (A. Y. Chiu and F. Strumwasser, manuscript in preparation).

In most animals, there appears to be a region of discontinuity in the staining, in the middle of the PVC, of up to $2 \mathrm{~cm}$. However, in two very large $A$. californica (body weight $>3 \mathrm{~kg}$; reproductive tract weight $\geq 20 \mathrm{gm}$ ), a few longitudinal immunopositive fibers are seen as far as $5.5 \mathrm{~cm}$ from the bag cell clusters, running within the PVC nerve trunk, which had a total length of $7 \mathrm{~cm}$. It is possible that a small number of longitudinal fibers, or fibers of small caliber in this middle region of the PVC, were not stained detectably in the smaller animals.

The tendency of bag cell processes to spiral around neighboring nerves is also expressed as a ring of stained neurites encircling the vulvar nerve (Fig. 2, $A$ and $B, v$ ). Other peripheral nerves are free of such a cuff, probably because they are more distant from the clusters. The example of spiraling neurites from an ectopic bag cell in the branchial nerve, described below, suggests that bag cell processes do not discriminate against cuff formation around the more caudally located peripheral nerves.

Bag cell processes often invade the interior of the abdominal ganglion by being associated with septal sheets of connective tissue (Figs. 3 and 4). Where such septa partition off groups of abdominal ganglion neurons, ELH-bearing processes may trace the septal divisions and surround some neuronal clusters within the abdominal ganglion. When a septum bisects the ganglion, bag cell processes run along in an anteroposterior corridor between the two hemiganglia (Fig. 4, $A, C$, and $D$, aps).

The majority of stained processes appear to be neurosecretory in function because of their close association with the vascularized connective tissue sheath. However, some immunoreactive fibers are seen arising from bag cells which ascend within the PVC nerve trunk or descend into the neuropil of the abdominal ganglion where they course across the commissure which links left and right halves of the ganglionic neuropil (Figs. $4 B$ and 5).

Although all neurons within bag cell clusters stain for ELH and none of the large ganglionic neurons are immunoreactive, a few scattered immunoreactive cells $(\sim 10$ per ganglion) can be seen in different parts of the ganglion outside of the confines of the clusters in 11 of the 12 animals examined (Fig. 4, $C$ and $D$ ). Some of these ectopic, ELH-immunoreactive cells also have been located within the PVC nerve (Fig. $6 A$ ), others have been found adjacent to a septum, and one was displaced as far 


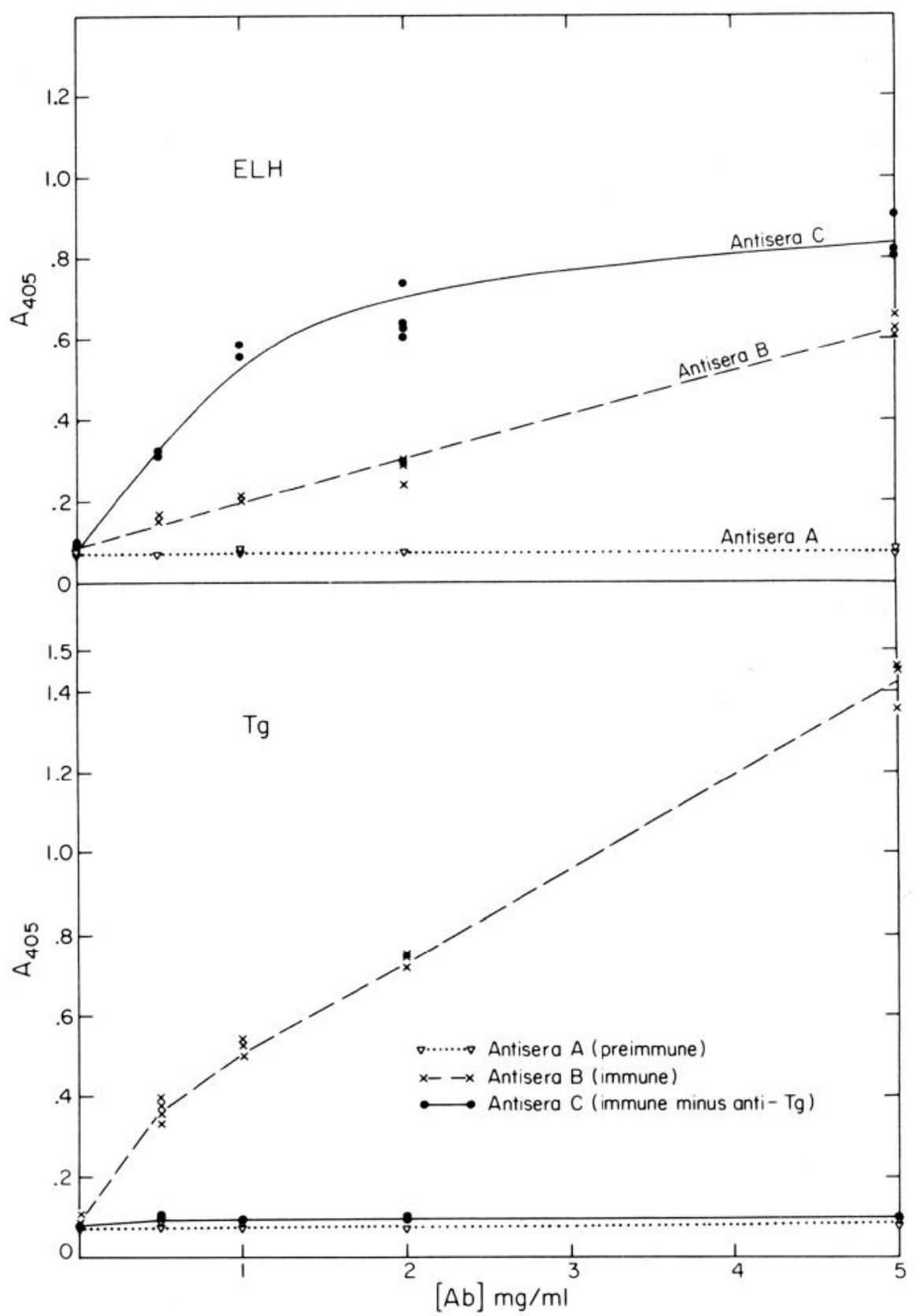

Figure 1. ELISA quantitation of anti-ELH and anti-Tg titer. Rabbit preimmune IgG (antisera A), immune IgG (antisera B), and immune IgG after removal of anti-Tg antibodies by affinity chromatography (antisera $\mathrm{C}$ ) each were tested against hapten (ELH)- or carrier (Tg)-coated wells. Bound rabbit antibodies, after rinsing, were treated with goat-anti-rabbit alkaline phosphatase conjugate, and enzyme activity was measured by reaction with $p$-nitrophenyl phosphate. Antisera titer is expressed as absorbance at $405 \mathrm{~nm}$. Upper, When tested in wells coated with $5 \mu \mathrm{g} / \mathrm{ml}$ of pure ELH, both immune antisera B and C show increasing binding with increasing antibody concentrations ([Ab]); however, antiserum $\mathrm{C}$ has a higher titer than antiserum $\mathrm{B}$, which still contains antibodies against Tg. Lower, Strong binding to Tg (wells coated with $20 \mu \mathrm{g} / \mathrm{ml}$ ) is seen only with antiserum $\mathrm{B}$. Antiserum $\mathrm{C}$, which has passed through a Tg-conjugated Sepharose column, shows a reduced titer of anti-Tg, not anti-ELH antibodies. No binding is seen when antiserum $\mathrm{A}$ is reacted against either antigen.

as the caudally located branchial nerve (Fig. $6 B$ ). Ectopic or displaced immunoreactive cells have dimensions similar to those of bag cells (Table I). Although they are not uncommon, ectopic cells are never seen consistently in any one location; their distribution varies greatly from ganglion to ganglion. In general, they tend to be more common in the rostral half of the ganglion but, as mentioned above, may be found as far away from the clusters 

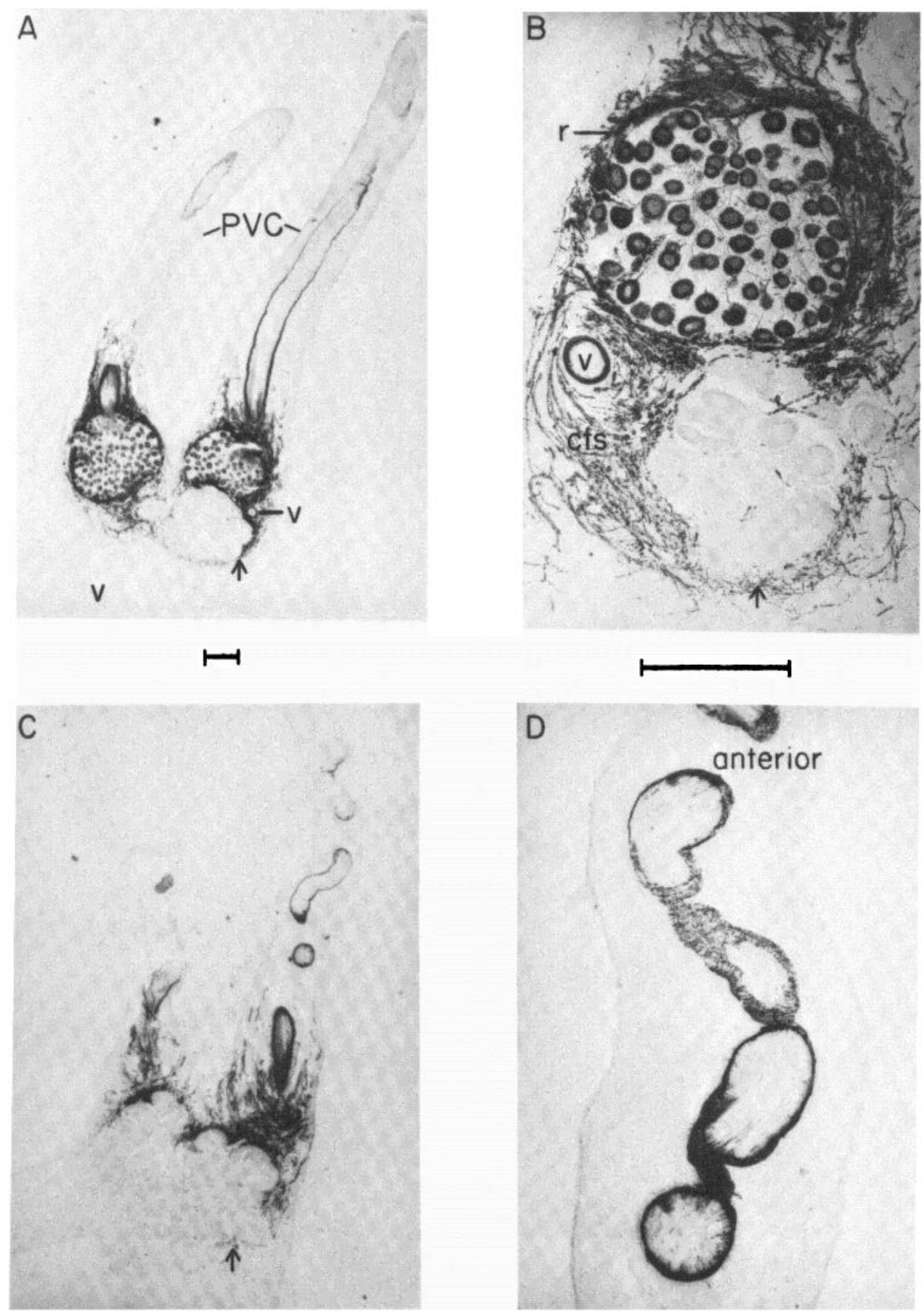

Figure 2. Cryostat sections of the abdominal ganglion of $A$. californica immunostained with antisera $\mathrm{C}$ by the PAP method. $A$, Whole transverse section shows immunoreactive bag cell somata confined within two clusters with processes ringing the periphery and extending into the ganglionic sheath as well as anteriorly into both PVCs. A cuff of ELH+ processes outlines each PVC nerve trunk; $v$ points to another cuff, appearing as a ring in cross-section around the vulvar nerve. $B$, Higher magnification reveals darkly stained perikarya within all bag cell somata. Though ELH+ processes are sparse within the cluster, they ramify at the rim $(r)$, sending branches rostrally, caudally, and medially into the connective tissue sheath ( cts). A few stained branches are seen, associated with septa, among the large, unstained neurons of the ganglion. $C$, A section dorsal to the bag cell clusters shows that the stained processes are densest in the rostral part of the ganglionic sheath; some still extend to the caudal margins (arrows) of the ganglion. Stained crosssections of the PVC cuff diminish in intensity with distance from the ganglion. All abdominal ganglion neurons in this and other sections are unreactive. $D$, Several crosssections of the spiraling cuff of processes show, in detail, the reduction of staining in more anterior regions of the PVC. $A$ and $C$ share the small scale bar; $B$ and $D$ share the large bar. Both bars represent $500 \mu \mathrm{m}$. 
TABLE I

Mean $^{a}$ somal and nuclear dimensions of bag cells and ectopic cells

\begin{tabular}{|c|c|c|c|c|c|c|c|c|c|c|}
\hline & \multirow[t]{2}{*}{$n$} & \multicolumn{2}{|c|}{$\begin{array}{c}\text { Major Somal } \\
\text { Diameter }\end{array}$} & \multicolumn{2}{|c|}{$\begin{array}{c}\text { Minor Somal } \\
\text { Diameter }\end{array}$} & \multirow[t]{2}{*}{$n$} & \multicolumn{2}{|c|}{$\begin{array}{c}\text { Major } \\
\text { Nuclear } \\
\text { Diameter }\end{array}$} & \multicolumn{2}{|c|}{$\begin{array}{c}\text { Minor } \\
\text { Nuclear } \\
\text { Diameter }\end{array}$} \\
\hline & & Mean & SEM & Mean & SEM & & Mean & SEM & Mean & SEM \\
\hline & & \multicolumn{2}{|c|}{$\mu m$} & \multicolumn{2}{|c|}{$\mu m$} & & \multicolumn{2}{|c|}{$\mu m$} & \multicolumn{2}{|c|}{$\mu m$} \\
\hline Bag cells & 1217 & 86.58 & 7.52 & 62.20 & 4.82 & 996 & 46.70 & 4.21 & 29.33 & 1.99 \\
\hline Ectopic cells & 79 & 97.16 & 11.17 & 61.15 & 5.89 & 59 & 48.90 & 4.93 & 30.50 & 4.30 \\
\hline
\end{tabular}

${ }^{a}$ The mean dimensions of six animals were averaged.
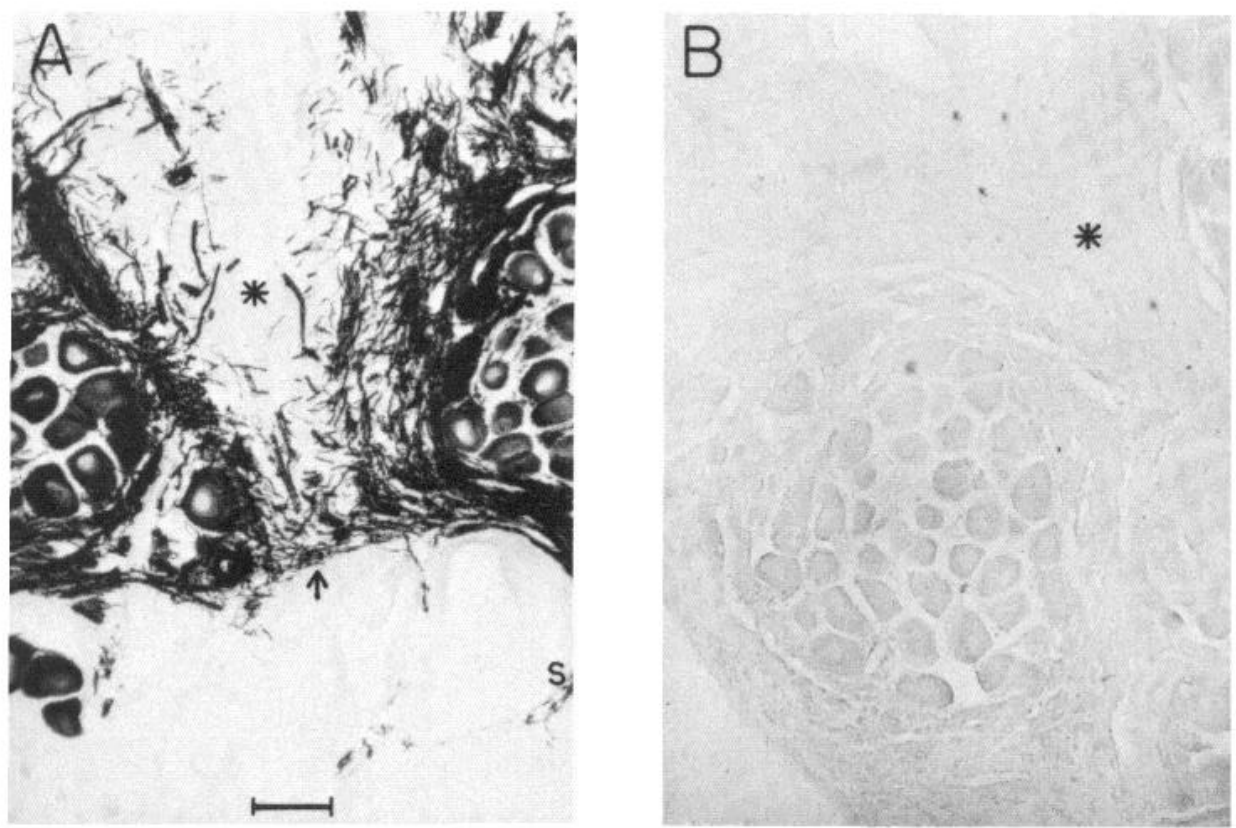

Figure 3. A, Medially directed immunoreactive processes (arrow) in the connective tissue sheath between bag cell clusters. These presumably serve to couple the electrical activities of the two clusters of neurosecretory cells. ELH+ processes also invade the ganglion with septa adjacent to the unstained large neurons caudal to the right cluster. Three immunopositive ectopic cells are seen outside and below the left cluster. B, A typical section, treated with pre-immune antisera $A$, shows no immunoreactivity. The bag cell cluster is unstained and no stained processes can be seen in the connective tissue sheath, such as between bag cell clusters $(*)$, in contrast to similar sections treated with immune serum, such as $A$. This control section was photographed at a lower exposure than the experimental pictures so that details of cells and other structures can be distinguished. Bar in $A$ represents $200 \mu \mathrm{m}$ for both sections.

as in the branchial nerve. Because of its atypical location, isolated from other immunoreactive cells and processes, this branchial nerve ectopic cell illustrates the variety and complexity of axonal projections that a single "bag" cell is capable of producing. Examined in multiple sections, this single stained cell extended neurosecretory processes into the connective tissue sheath of the nerve as well as a cuff of spiraling processes around the branchial nerve (Fig. $6 B$ ).

Aplysia braziliana, Aplysia dactylomela, and Aplysia vaccaria. In these three species of Aplysia, the bag cell clusters are consistently strongly stained by immune antisera C to A. californica ELH (Fig. 7). A. braziliana $(n=3)$ shares the extensive and complex branching pattern of processes seen in A. californica (Fig. $7 C$ ). Because the $A$. braziliana abdominal ganglion has a shorter anteroposterior axis, bag cell processes of the connective tissue sheath appear to envelope the whole ganglion more completely than in A. californica with dense immunoreactive processes frequently seen at the caudal margins. Groups of ectopic cells also appear more frequently and stained processes have been seen to invade the connective tissue sheath of the caudally placed peripheral nerves. In A. californica ganglia, this was seen only in the one instance when an ectopic cell and its processes were located in the branchial nerve. The bag cells of $A$. braziliana also send a cuff of processes around the proximal end of the pleurovisceral nerve as well as medial processes between the clusters.

The immunopositive bag cell system of a small $A$. dactylomela $(n=1)$ does not appear to differ greatly from those of $A$. californica and A. braziliana except for a general reduction in size commensurate with the smaller dimensions of its abdominal ganglion (Fig. $7 B$ ). While a prominent cuff of neurites extends up each PVC, neurosecretory processes within the connective tissue 

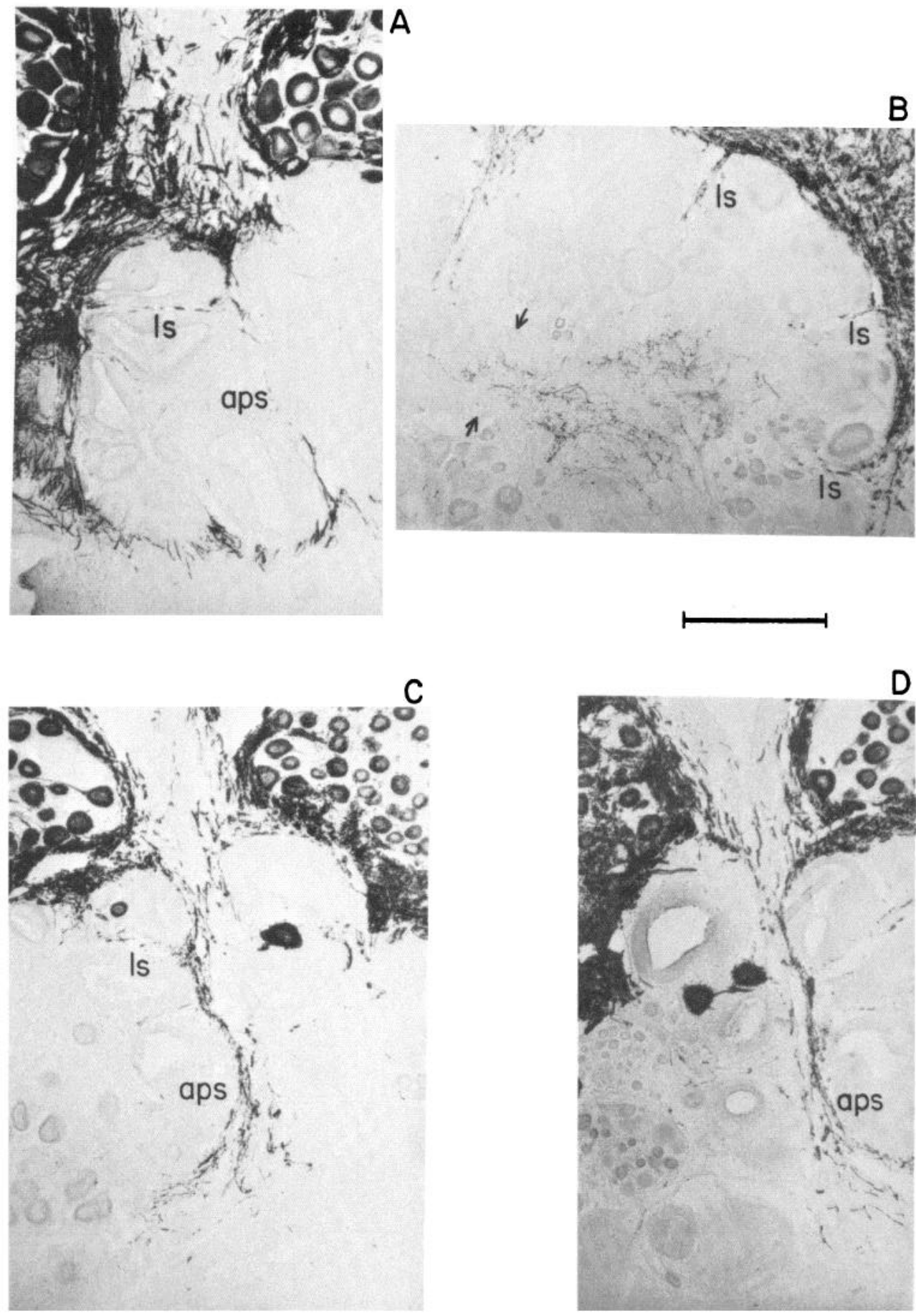

Figure 4. Immunopositive processes, associated with connective tissue septa, travel into the abdominal ganglion. In $A, C$, and $D$, bundles of processes course along an anteroposterior (aps) corridor within the ganglion. More laterally oriented septa in $A, B$, and $C$ also bear processes $(l s) . B$ shows shallow invasions of neurites from the connective tissue sheath, dense with bag cell processes, in the upper right corner. ELH+ fibers in the neuropil travel into the commissure (arrows). Ectopic bag cells, one with a process, are seen among unreactive neurons in the ganglion in $C$ and $D$. Bar represents $500 \mu \mathrm{m}$.

sheath are less dense than the networks of $A$. californica and $A$. braziliana and do not appear to extend beyond the rostral half of the ganglion. We cannot exclude the possibility that the range of processes is a function of sexual maturity.

In marked contrast to their counterparts in the other three species of Aplysia, the bag cells of $A$. vaccaria ( $n$ $=6$; reproductive tract weights from 0.2 to $9.3 \mathrm{gm}$ ) show a very limited array of extended processes (Fig. $7 A$ ). No network of stained neurites can be seen in the connective tissue sheath of their abdominal ganglia and there is a conspicuous lack of processes running between clusters. 


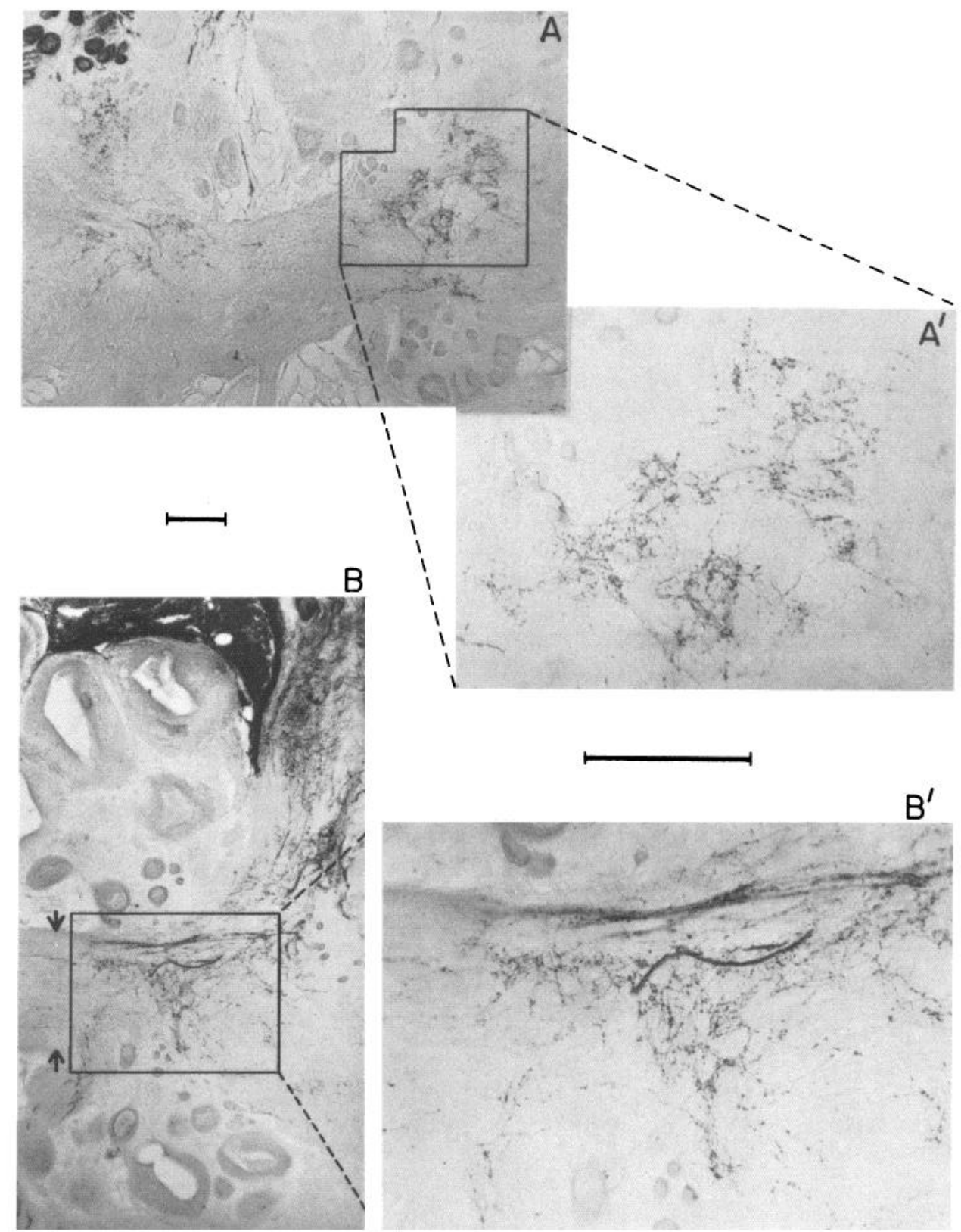

Figure 5. Immunoreactive fibers within the neuropil and commissure of the abdominal ganglion. $A$, A network of fibers is present within the neuropil on both sides of the ganglionic commissure (box over right side only). $B$, These fibers descend from the bag cell clusters along the PVC nerve into the neuropil; some travel across the commissure (arrows) to the neuropil of the contralateral hemiganglion. A longitudinal section of the medial side of the PVC nerve cuff appears at the upper right. $A^{\prime}$ and $B^{\prime}$ show beaded fibers, within the boxed areas of $A$ and $B$, respectively, at higher magnification. Bars represent $200 \mu \mathrm{m}$.

Within the prominent clusters, intercellular spaces are packed densely with stained material which may represent a high investment of coiled bag cell processes. Except for the presence of a reduced cuff spiraling around the proximal PVC nerves, no other stained process can be seen beyond the confines of the cluster in all $A$. vaccaria examined (over 150 sections). However, as these animals were collected during a 4-month period, between October 1979 and February 1980, we cannot rule out seasonal variability in the distribution of bag cell processes in $A$. vaccaria.
Immunofluorescent studies on primary cultures of Aplysia neurons. There are advantages in applying immunofluorescent staining to bag cells in primary culture since a single bag cell, with all of its processes, could be viewed in its entirety as opposed to sectioned material. Intensely fluorescent immunoreactivity to ELH was displayed by all bag cell neurons in cultures of from 1 to 4 days (Fig. 8) in sharp contrast to the controls of bag cells treated with pre-immune sera and of other cultured Aplysia neurons from two other sources after reaction with either antisera $\mathrm{A}$ or antisera $\mathrm{C}$. 

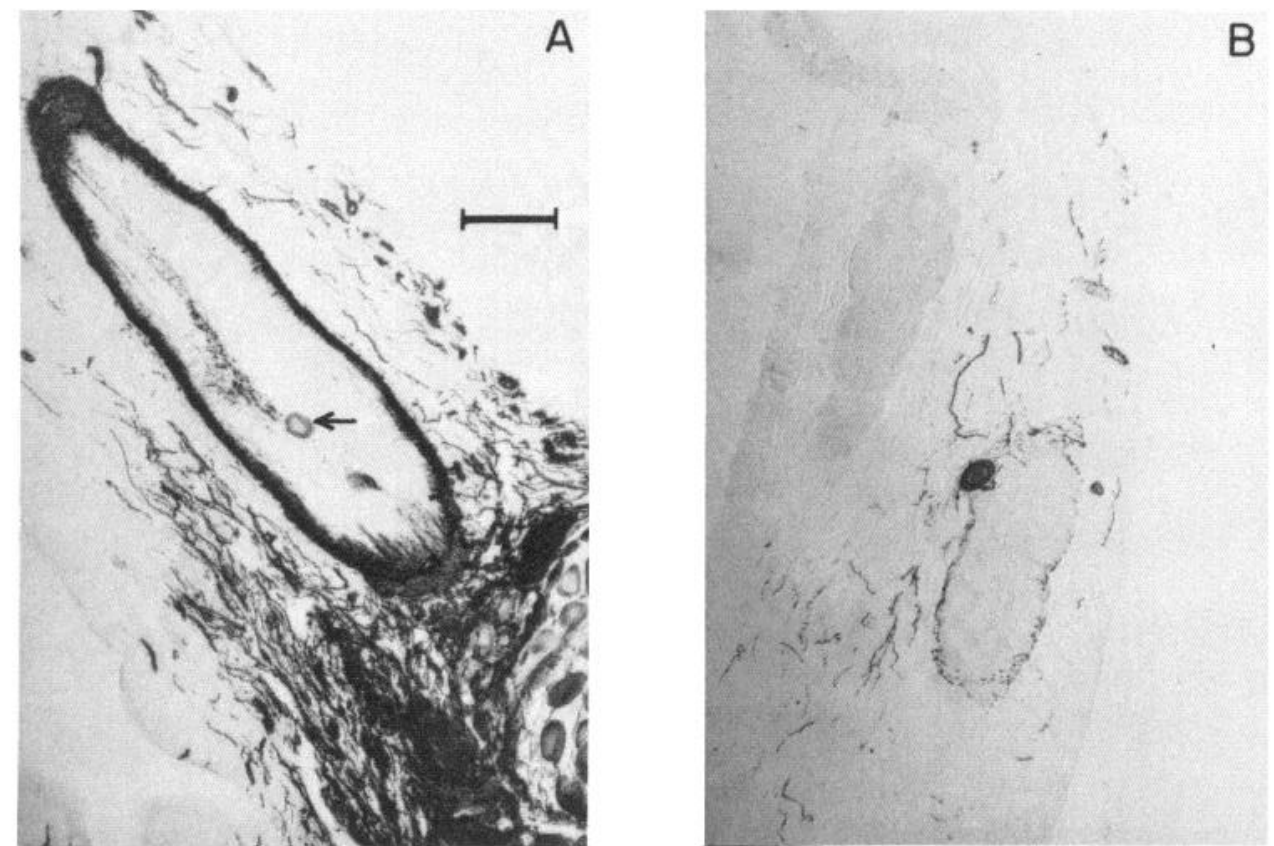

Figure 6. Ectopic bag cells within nerve trunks leading from the abdominal ganglion. $A$, Cross-section of a PVC nerve trunk, encircled by a deeply stained cuff of processes, reveals a soma (arrow) with ELH+ perikaryon and unstained nucleus similar to those within the bag cell cluster at lower right. $B$, A single displaced immunoreactive cell in the branchial nerve gives rise to processes wrapped around the branchial nerve trunk as well as neurites ramifying in the sheath of the nerve. Bar represents $250 \mu \mathrm{m}$ on $A$ and $B$.

In many preparations, it was possible to note heterogeneity of staining within the bag cell soma: the nucleus can be distinguished clearly as a dark, asymmetrically located ovoid encircled by a richly fluorescent perinuclear ring which fills up most of the rest of the cell body (Fig. $8 B$ ). Around the edge of the cell body, there are occasional unstained vacuoles which may represent lysosomes and are not expected to contain immunoreactive ELH. Often, the edge of the soma extends in a sheet or web over the substrate before processes project away from it. Such extensions and all neurites of bag cells are also immunoreactive though to a lesser degree than the perinuclear ring. Putative glial cells, present in bag cell cultures and identified by their small size, showed faint background staining similar to bag cells and glial cells stained with pre-immune serum.

Primary cultures of $A$. californica eye and buccal ganglion neurons, 1 to 2 days after seeding, also were reacted with pre-immune or immune sera. These are heterogeneous populations of neuronal cell types, but in all cases, no specific immunoreactivity was seen associated with any cell type.

\section{Discussion}

These immunohistochemical studies are the first to show the topographic distribution of ELH+ cells and processes in cryostat sections of the abdominal ganglion and its neighboring nerves. Our observation that all neurons within bag cell clusters are immunopositive in all 12 Aplysia californica examined establishes bag cell clusters as homogeneous populations of ELH-producing, neurosecretory cells antigenically distinct from the other neurons of the abdominal ganglion. The extensive array of immunoreactive processes provides important anatomical support for the model of local hormonal action of bag cells on the activities of other neurons within the ganglion (Mayeri, 1979). This distribution of neurites is also consistent with electrophysiological studies on the coupling of afterdischarges between clusters (Kupfermann and Kandel, 1970; Haskins and Blankenship, 1979). The observed "cuff," organized in close apposition to the proximal PVC nerve trunk, may contain contacts between putative driver neurons in the head ganglia and the bag cell system. Finally, in studies carried out on three other species of Aplysia, we report the presence of a molecule(s) in their bag cell systems which shares antigenic determinants with $A$. californica ELH.

Are bag cells homogeneous? It is known that, besides $\mathrm{ELH}$, at least three other peptides are released by bag cell clusters during a single afterdischarge in vitro (Stuart et al., 1980). The functional significance of these peptides is not presently known and raises the question whether the bag cells are heterogeneous in their production of these peptides. Our observation that all neuronal somata within bag cell clusters show strong immunoreactivity for ELH supports the hypothesis that all bag cells produce ELH. Our results cannot rule out the possibility that bag cells may still be heterogeneous in their ability to synthesize and release some of the other, less well characterized neurosecretory products which are also released during an afterdischarge. While it is clear from the cell culture results that the glial cells are not immunoreactive for ELH, it is not known whether any of these other secretory products are glial in origin.

In studies where intracellular injections of Lucifer Yellow allowed visualization of the neuritic arborization of 

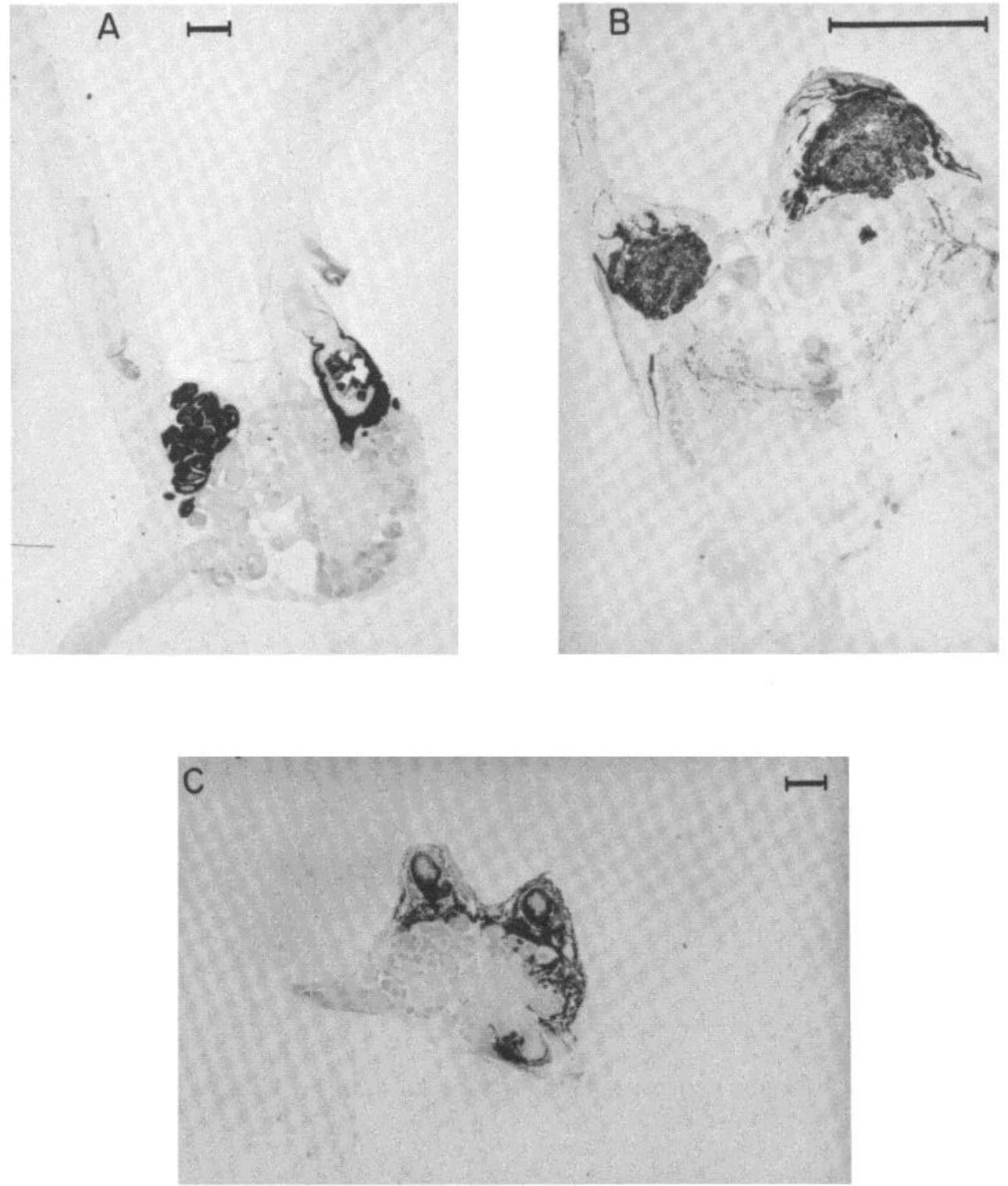

Figure 7. ELH-like immunoreactivity in the bag cell systems of other Aplysia species. $A, A$. vaccaria: While bag cells and processes at the edge of the cluster and cuffing the PVC nerves are strongly immunoreactive, no other stained processes can be seen within the sheath of the ganglion. Conspicuously absent are neurites between the two clusters. $B$, A. dactylomela: Two clusters of tightly packed ELH+ cells send some stained processes into the sheath. Fibers can clearly be seen within both sides of the neuropil, crossing the commissure in the middle. A small group of ectopic cells are present beneath the right cluster. $C, A$. braziliana: This section cuts through both PVC nerves displaying the dense cuff. Processes within the sheath continue to the caudal aspect of the ganglion; ectopic cells can be seen as far as at the junction of the branchial nerve and the abdominal ganglion. Bars represent $500 \mu \mathrm{m}$.

single cells, the direction of bag cell process extension was variable (Kaczmarek et al., 1979). We have described several types of immunoreactive processes-those associated with the sheath, cuff processes, and fibers within the neuropil. The possibility then arises that there may be several subgroups of ELH-bearing bag cells, each producing a separate class of process, which would argue against morphological homogeneity. While we cannot exclude completely the possibility that a small but distinct population of bag cells only send their processes to the neuropil, the example of an ectopic immunoreactive cell in the branchial nerve demonstrates the ability of one cell to send out the other two types of processes.

Not all immunoreactive cells are found within the confines of the bag cell clusters; about 10 stained cells have been found in other parts of the abdominal ganglion or neighboring nerve tracts in every animal examined. One possibility is that these cells contain some product which shares immunoreactive determinants with ELH but bear no other kinship to bag cells. A second and more 

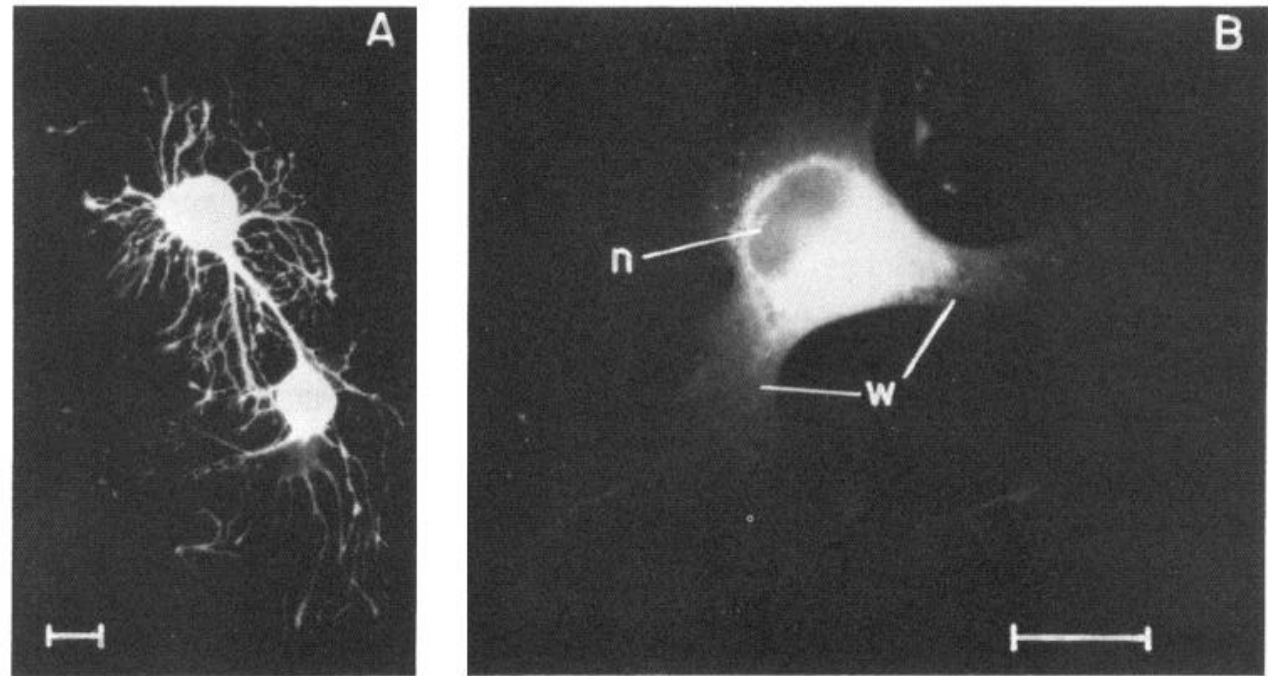

Figure 8. Immunofluorescent staining of primary cultures of bag cells. These 4-day-old cultured bag cells were fixed in formaldehyde and treated with cold acid/alcohol prior to reaction with antisera $\mathrm{C}$, followed by fluorescein isothiocyanate-conjugated goat-antirabbit IgG. $A$, Cultured bag cells often become electrically recoupled (Kaczmarek et al., 1979). The proximity of this pair of intensely stained somata, and the presence of two, thick, immunoreactive processes between them, makes it likely that these cells are coupled. $B$, At this level of focus, the unstained ovoid nucleus $(n)$ of this bag cell is contrasted with strongly immunoreactive material within the perikaryon. A thin "web" $(w)$ or sheet of cytoplasm, spreading from the lower left and right corners of the soma, leads to numerous processes. Bars represent $50 \mu \mathrm{m}$.

attractive explanation is that these are ELH-bearing ectopic cells of bag cell origin which have migrated to inappropriate locations during development. Several points are consistent with the latter explanation: (i) Location of these cells varies greatly from ganglion to ganglion, suggesting that they are not members of another defined group of abdominal ganglion neurons; (ii) their cell size does not differ greatly from that of bag cells (Table I); (iii) when neurites are seen emanating from these cells, they resemble those of bag cells, again attesting to a common origin (Fig. $6 \mathrm{~B}$ ); (iv) the presence of a small discrete group of ELH-immunoreactive neurons, which bear a striking resemblance to bag cells, in the pleural ganglia (A. Y. Chiu and F. Strumwasser, manuscript in preparation) strengthens the possibility that precursors of bag cells migrate during development.

In developing vertebrate systems, many cells, including displaced ones, are often eliminated when they fail to make appropriate synaptic contacts with postsynaptic targets (Lund, 1978). However, since bag cells are neuroendocrine cells which presumably do not make synaptic contacts with their targets, these ectopic cells may not have been programmed for elimination.

Morphological correlates of local hormone action. Within the abdominal ganglion, we find $\mathrm{ELH}+$ processes associated with septa as well as stained fibers within the neuropil and traversing the commissure which links left and right hemiganglia. Septa are extensions of the connective tissue sheath which invade and partition the ganglion as the animal grows (Kandel, 1979). Since the majority of bag cell neurosecretory processes are associated intimately with the superficial envelope of connective tissue overlying the ganglion, this association ap- pears to continue with the development of septa as the ganglion matures.

Mayeri and colleagues have proposed that bag cells modulate the activity of other neurons within the abdominal ganglion by local release of neurohormones during an afterdischarge (Branton et al., 1978; Mayeri, 1979). The responses of the target neurons are characteristically long lasting with slow and smoothly graded onsets and differ from responses at conventional synapses. They have shown further that some of the excitatory effects can be mimicked by direct application of ELH onto a target neuron, R15 (Branton et al., 1978), while inhibitory responses may be mediated by a different product of the bag cell cluster (Rothman et al., 1979). Our results provide morphological support for this model; we note three routes through which such local hormonal action can be brought about. Firstly, the cortex of neuronal somata in the abdominal ganglion is enveloped by an overlying sheath densely infiltrated by ELH+ processes. Secondly, in the interior of the ganglion, septa bearing bag cell neurites frequently lie in close proximity to cell bodies. Finally, immunoreactive fibers course through the neuropil amid processes of other neurons. It is likely, in these three instances, that bag cell neurohormones can readily reach somal or dendritic receptors on nearby neurons when released during an afterdischarge.

Our studies suggest that Aplysia vaccaria provides an ideal preparation in which to test the local hormone action model. We notice that, except for a PVC cuff and processes within the cluster, its abdominal ganglion lacks all other types of immunoreactive bag cell processes. Target neurons within the ganglion would have access only to bag cell neurohormones through the hemolymph. 
Therefore, it would be of great interest to see if prospective target neurons respond to bag cell products and whether these responses still occur concomitant with a bag cell afterdischarge as they do in A. californicu (Mayeri, 1979).

Possible roles of bag cell organized cuff. One of the unique morphological features of the bag cell system is the highly organized cylindrical cuff of ELH+ processes arranged just outside of the core of the nerve trunks. While the presence of a cuff of neurosecretory processes, presumably from bag cells, has been described by ultrastructural criteria by Frazier and colleagues (1967), the PAP immunocytochemical technique has allowed a clear demonstration of this structure at the light microscope level.

The function for this cuff of bag cell processes in direct contact with the PVC nerve is not known. Release of neurohormones at these sites may modulate communications between abdominal ganglion neurons and those in the head ganglia at axonal levels, another form of local hormone action. A second possibility is that this region represents an area of direct synaptic inputs from the head ganglia onto bag cell processes. Stimulation of the peripheral nerves of the abdominal ganglion will not activate bag cells (Kupfermann and Kandel, 1970; L. K. Kaczmarek, personal communication), while direct stimulation of the pleural end of the PVC or of certain cell clusters in the cerebral ganglion will induce bag cells to afterdischarge (L. K. Kaczmarek and A. Y. Chiu, unpublished results). This suggests the presence of an orthodromic pathway which descends from the head ganglia to the bag cells. Consistent with this hypothesis are studies which show that bag cell action potentials typically originate from the distal neurites of the PVC nerve and propagate inward toward the somata in the isolated abdominal ganglion (Dudek and Blankenship, 1977; Kaczmarek et al., 1978).

Alternatively, if bag cell processes extended all the way to the head ganglia, stimulation of the distal PVC would trigger the bag cells antidromically. However, in 10 out of 12 animals examined, immunoreactive processes from the bag cells are contained within the proximal $2 \mathrm{~cm}$ of the PVC. There appears to be no continuity between these processes and stained neurites at the pleural end of the connective, usually 2 to $3 \mathrm{~cm}$ away, which originate from several immunoreactive cells within the pleural ganglia (A. Y. Chiu and F. Strumwasser, manuscript in preparation). However, a very few $\mathrm{ELH}+$ fibers were found in the midsection of the PVCs and as far anteriorly as $5.5 \mathrm{~cm}$ from the bag cell cluster in two exceptionally large $A$. californica whose PVCs were $7 \mathrm{~cm}$ long. The presence of a small number of similar fibers in the PVC nerve of the smaller animals may have escaped detection by this technique. It is clear that afterdischarge can be initiated from the pleural end of the PVC in animals that clearly have no immunocytochemically evident bag cell processes in the middle portion of the PVC

Intercluster coupling. The initiation of an afterdischarge in one cluster will result in the activation of the contralateral cluster to afterdischarge within seconds. When the sheath capsule between two clusters was cut, such coupling also ceased (Kupfermann and Kandel,
1970). It is more than likely that such intercluster coupling is effected by the profusion of the medially directed immunoreactive processes that we see emanating from each cluster. In $A$. vaccaria, where such processes are conspicuously missing from stained sections, there is a concomitant lack of coupling between the pair of bag cell clusters (L. K. Kaczmarek and A. Y. Chiu, unpublished results).

In the neuropil, immunoreactive fibers are present but sparsely represented compared with the profusion of processes in the sheath. Since a shallow cut between clusters is sufficient to uncouple the activity of the two clusters, any intercluster communication via these deeper fibers probably does not play an important role in the transfer of afterdischarge. As discussed above, they may contribute to local hormonal effects as release sites within the neuropil. Earlier ultrastructural studies have revealed no chemical synapses between bag cell processes and other neurons within the sheath. It is not known, however, if bag cells make synaptic contacts with other neurons within the neuropil.

Neurohemal areas. Rapid introduction of neurohormones into the general circulation, a requisite of any effective neurosecretory system, is dependent upon the extent and efficacy of the neurohemal areas where neurosecretory surfaces are brought into close contact with the vascular system. In the abdominal ganglion, Frazier and colleagues (1967) described the general distribution of processes in the vascularized connective tissue sheath which contain $170 \mathrm{~nm}$, moderately dense core granules resembling those found in bag cell somata. They argued that such processes must be neurosecretory in function based on their content of granules, their proximity to sinus spaces within the sheath, and their conspicuous lack of functional contact with other axons and cells within the sheath. We extend their description in our visualization of the full scope of this neuritic network which is densest around the clusters but stretches to the caudal edges of the ganglion, especially on the ventral surface where the bag cell clusters are most prominent. The bag cell organ thus increases its neurosecretory surfaces immensely by utilizing the major part of the ganglionic surface as its neurohemal organ. More importantly, this study establishes the presence of the neurosecretory product, ELH, in these hitherto presumed neurosecretory processes. It is highly likely that the 170 $\mathrm{nm}$ granules actually contain ELH and other secreted bag cell peptides; however, this awaits verification by immunohistochemical studies at the electron microscopic level.

Comparative studies in other species. Antiserum, generated against ELH purified from $A$. californica, subgenus Neoaplysia, specifically cross-reacts with the bag cell systems of three other species of Aplysia from two other subgenera: Aplysia braziliana and Aplysia dactylomela, subgenus Varria, and $A$. vaccaria of subgenus Aplysia. As in $A$. californica, the bag cell clusters of these three species are also homogeneous populations of immunoreactive neurons. It is reassuring to note that, in the three species where intercluster transfer of afterdischarge has been reported (Haskins and Blankenship, 1979), we also find the medially ex- 
tending processes in the sheath between clusters which couple such activity.

Other investigators have found that extracts of $A$. californica abdominal ganglia will induce egg-laying activity in these other three Aplysiads which we have studied. Extracts containing the ELH of $A$. vaccaria or A. braziliana, in turn, will cause oviposition in $A$. californica ( $A$. braziliana, J. Blankenship, personal communication; $A$. vaccaria and $A$. dactylomela, see Toevs, 1970). Our demonstration of cross-immunoreactivity and the evidence of cross-bioactivity between these specics make it likely that, if the ELHs of these four species of Aplysia are not identical, at least the receptor binding sites and antigenic determinants of these molecules must be highly conserved.

\section{References}

Arch, S. (1972) Polypeptide secretion from the isolated PVG of Aplysia californica. J. Gen. Physiol. 59: 47-59.

Arch, S. (1976) Neuroendocrine regulation of egg laying in Aplysia californica. Am. Zool. 16: 167-175.

Blankenship, J. E., and J. T. Haskins (1979) Electronic coupling among neuroendocrine cells in Aplysia. J. Neurophysiol. 42: 347-355.

Branton, W. D., S. Arch, T. Smock, and E. Mayeri (1978) Evidence for mediation of a neuronal interaction by a behaviorally active peptide. Proc. Natl. Acad. Sci. U. S. A. 75: $5732-5736$.

Chiu, A. Y., M. Hunkapiller, E. Heller, D. K. Stuart, L. E. Hood, and F. Strumwasser (1979a) Purification and primary structure of the neuropeptide egg-laying hormone of Aplysia californica. Proc. Natl. Acad. Sci. U. S. A. 76: 6656-6661.

Chiu, A. Y., M. Hunkapiller, and F. Strumwasser (1979b) The neuropeptide, ELH of Aplysia: Purification, amino acid sequence and antibodies. Soc. Neurosci. Abstr. 5: 243.

Coggeshall, R. E. (1967) A light and electron microscope study of the abdominal ganglion of Aplysia californica. J. Neurophysiol. 30: 1263-1287.

de Wied, D., and D. H. G. Verskeg (1979) Neurohypophyseal principles and memory. Fed. Proc. 38: 2348-2354.

Dudek, F. E., and J. E. Blankenship (1977) Neuroendocrine cells of Aplysia braziliana. I. Bag cell potentials and afterdischarge. J. Neurophysiol. 40: 1301-1311.

Dyer, R. G., and R. E. J. Dyball (1974) Evidence for a direct effect of LRF and TRF on single unit activity in the rostral hypothalamus. Nature 252: 486-488.

Elde, R., and T. Hökfelt (1978) Distribution of hypothalamic hormones and other peptides in the brain. In Frontiers in Neuroendocrinology, L. Martini and W. F. Ganong, eds., pp. 1-33, Raven Press, New York.

Engvall, E., and P. Perlmann (1972) Enzyme-linked immunosorbent assay, ELISA. III. Quantitation of specific antibodies by enzyme-labeled antiimmunoglobin in antigen-coated tubes. J. Immunol. 109: 129-135.

Frazier, W. T., E. R. Kandel, I. Kupfermann, R. Waziri, and R. E. Coggeshall (1967) Morphological and functional properties of identified neurons in the abdominal ganglion of Aplysia californica. J. Neurophysiol. 30: 1288-1351.

Garvey, J. S., N. E. Cremer, and D. H. Sussdorf (1977) Methods in Immunology, Ed. 3, John Wiley, New York.

Haskins, J. T., and J. E. Blankenship (1979) Interactions between bilateral clusters of neuroendocrine cells in Aplysia. J. Neurophysiol. 42: 356-367.

Hokfelt, T., J. M. Lundberg, M. Schultzberg, O. Johansson, $\AA$. Ljungdahl, and J. Rehfeld (1980a) Coexistence of peptides and putative transmitters in neurons. In Advances in Biochemical Psychopharmacology. Vol. 22: Neural Peptides and Neuronal Communication, E. Costa and M. Trabuschi, eds., pp. 1-24, Raven Press, New York.

Hökfelt, T., O. Johansson, Å. Ljungdahl, J. M. Lundberg, and M. Schultzberg (1980b) Peptidergic neurones. Nature 284: 515-521.

Jackson, I. M. D., and S. Reichlin (1979) Distribution and biosynthesis of TRM in the nervous system. In Central Nervous System Effects of Hypothalamic Hormones and Other Peptides, pp. 3-54, Raven Press, New York.

Jan, Y. N., L. Y. Jan, and S. W. Kuffler (1979) A peptide as a possible transmitter in sympathetic ganglia of the frog. Proc. Natl. Acad. Sci. U. S. A. 76: 1501-1505.

Jan, L. Y., Y. N. Jan, and M. S. Brownfield (1980) Peptidergic transmitters in synaptic boutons of sympathetic ganglia. $\mathrm{Na}$ ture 288: $380-382$.

Kaczmarek, L. K., K. Jennings, and F. Strumwasser (1978) Neurotransmitter modulation, phosphodiesterase inhibitor effects and cyclic AMP correlates of afterdischarge in peptidergic neurites. Proc. Natl. Acad. Sci. U. S. A. 75: 5200-5204.

Kaczmarek, L. K., M. Finbow, J. P. Revel, and F. Strumwasser (1979) The morphology and coupling of Aplysia bag cells within the abdominal ganglion and in cell culture. J. Neurobiol. 10: 535-550.

Kandel, E. R. (1979) Behavioral Biology of Aplysia, pp. 150151, Freeman Press, San Francisco.

Kupfermann, I., and E. R. Kandel (1970) Electrophysiological properties and functional interconnections of two symmetrical neurosecretory clusters (bag cells) in abdominal ganglion of Aplysia. J. Neurophysiol. 33: 865-876.

Loh, Y. P., Y. Sarne, and H. Gainer (1975) Heterogeneity of proteins synthesized, stored, and released by the bag cells of Aplysia californica. J. Comp. Physiol. 100: 283-295.

Lund, R. D. (1978) Development and Plasticity of the Brain, Oxford University Press, New York.

March, S. C., I. Parikh, and P. Cuatrecasas (1974) A simplified method for cyanogen bromide activation of agarose for affinity chromatography. Anal. Biochem. 60: 149-152.

Mayeri, E. (1979) Local hormonal modulation of neural activity in Aplysia. Fed. Proc. 38: 2103-2108.

Moss, R. L. (1979) Actions of hypothalamic-hypophysiotropic hormones on the brain. Annu. Rev. Physiol. 41: 617-631.

Renaud, L. P., and A. Padjen (1977) Electrophysiological analysis of peptide actions in neural tissue. In Centrally Acting Peptides, J. Hughes, ed., pp. 59-84, University Park Press, Baltimore.

Rothman, B. S., P. Brownell, and E. Mayeri (1979) Purified bag cell peptide mimicks some but not all responses of central neurons to bag cell stimulation in Aplysia. Soc. Neurosci. Abstr. 5: 260.

Schlesinger, D. H., S. P. Babirak, and J. E. Blankenship (1981) Primary structure of an egg-releasing peptide from the atrial gland of Aplysia californica. In Symposium on Neurohypophyseal Peptide Hormones and Other Biologically Active Peptides, D. H. Schlesinger, ed., Elsevier-North Holland Publishing Co., New York, in press.

Silverman, A. J., and E. A. Zimmerman (1978) Pathways containing luteinizing hormone-releasing hormone (LHRH) in the mammalian brain. In Brain Endocrine Interaction. III. Neural Hormones and Reproduction, 3rd International Symposium, Wurzburg, pp. 83-96, Karger, Basel, Switzerland.

Smock, T., and S. Arch (1977) A cytochemical study of the bag cell organs of Aplysia californica. J. Histochem. Cytochem. 25: $1345-1350$.

Straus, W. (1971) Inhibition of peroxidase by methanol and by methanol-nitroferricyanide for use in immunoperoxidase procedures. J. Histochem. Cytochem. 19: 682-688.

Strumwasser, F., L. K. Kaczmarek, and D. Viele (1978) The peptidergic bag cell neurons of Aplysia: Morphological and 
electrophysiological studies of dissociated cells in tissue culture. Soc. Neurosci. Abstr. 4: 645.

Strumwasser, F., L. K. Kaczmarek, A. Y. Chiu, E. Heller, K. R. Jennings, and D. P. Viele (1980) Peptides controlling behavior in Aplysia. In Society of General Physiologists Series. Vol. 35: Peptides: Integrators of Cell and Tissue Function, F. E. Bloom, ed., pp. 197-218, Raven Press, New York.

Stuart, D. K., A. Y. Chiu, and F. Strumwasser (1980) Neurosecretion of egg-laying hormone and other peptides from electrically active bag cell neurons of Aplysia. J. Neurophysiol. 43: $488-497$.
Swanson, L. W. (1977) Immunohistochemical evidence for a neurophysin-containing autonomic pathway arising in the paraventricular nucleus of the hypothalamus. Brain Res. 128: $346-353$

Toevs, L. (1970) Identification and characterization of the egglaying hormone from the neurosecretory bag cells of Aplysia. Doctoral dissertation, California Institute of Technology, Pasadena, CA.

Vaitukaitis, J., J. B. Robbins, E. Nieschlag, and G. T. Ross (1971) A method for producing specific antisera with small doses of immunogen. J. Clin. Endocrinol. Metab. 33: 988-991. 